\title{
Experimental Study on the Structural Performance Degradation of Corrosion-Damaged Reinforced Concrete Beams
}

\author{
Ju-Seong Jung, ${ }^{1}$ Bang Yeon Lee $\mathbb{D}{ }^{2},{ }^{2}$ and Kang-Seok Lee $\mathbb{D}^{3}$ \\ ${ }^{1}$ Department of Architectural Engineering, Hanyang University, Seoul, Republic of Korea \\ ${ }^{2}$ School of Architecture, Chonnam National University, Gwangju, Republic of Korea \\ ${ }^{3}$ Department of Architectural Engineering, Hanyang University, Ansan, Republic of Korea \\ Correspondence should be addressed to Kang-Seok Lee; ksleenist@hanyang.ac.kr
}

Received 20 June 2019; Accepted 16 September 2019; Published 16 October 2019

Guest Editor: Charis Apostolopoulos

Copyright (c) 2019 Ju-Seong Jung et al. This is an open access article distributed under the Creative Commons Attribution License, which permits unrestricted use, distribution, and reproduction in any medium, provided the original work is properly cited.

\begin{abstract}
It is very important to investigate the effects of the seismic performance of corrosion-damaged reinforced concrete (RC) members, in terms of their strength and lateral deformability, on the seismic performance of entire building systems. Such investigation allows accurate evaluation of the seismic performance of RC structures with corroded members, including beams and columns. However, current techniques for evaluating the seismic performance of existing RC structures do not take the effects of deterioration (including the corrosion of reinforcing bars) on the performance of RC members into account. The main objective of this research is to propose a practical methodology for evaluating the seismic performance of RC buildings with corrosiondamaged members. We extrapolate a structural performance degradation factor from the strength-deformation capability of corroded members to allow direct quantitative evaluation of their seismic performance. In this study, as a first step toward achieving this goal, we experimentally investigated the effect of reinforcing bar corrosion on the behavior of RC beams and the structural performance degradation factor. Our analysis was based on the strength-deformation capabilities of corrosiondamaged beams. We also propose a relationship between the half-cell potential of corroded reinforcing bars and the structural performance degradation behavior of RC beams. Our results indicate that there is a relatively strong correlation between the performance degradation factor and the average potential difference, with coefficients of determination $\left(R^{2}\right)$ of the flexural and shear beams of 0.78 and 0.91 , respectively. The potential difference, which was measured using the half-cell measurement method, can serve as one of the indicators of relative structural degradation, but we must ensure that the environmental measurement conditions are held constant.
\end{abstract}

\section{Introduction}

Reinforced concrete (RC) structures are the most common structural systems in modern society, due to their low construction and maintenance costs and high durability compared to other types of structures. The structural performance of RC structures, however, deteriorates over time for various reasons, such as changes in the environmental conditions, design load, and material properties, as well as structural design errors and defective construction. Among these factors, reinforcement corrosion is one of the primary causes of deterioration, affecting a large number of RC structures [1-10]. This results in a shortened service life and reduced structural performance (Figure 1).
Major causes of this corrosion include chloride and carbonation, arising from elements of the atmosphere or surrounding environment such as the sea, de-icing salts, and pollution. Hansson [1] and Shamsad [4] investigated the corrosion mechanism of steel bars and the effects of corrosion on RC members; structural deterioration was found to proceed according to the following stages: (1) Formation of white patches: atmospheric carbon dioxide reacts with calcium hydroxide in the cement paste, forming calcium carbonate. This calcium carbonate is carried by moisture and deposited onto the concrete surface, forming white patches. (2) Brown patches in reinforced areas: when a steel bar starts to corrode, a layer of iron oxide is formed on top of the bar, which is carried to the surface of the concrete by moisture. (3) Formation of 


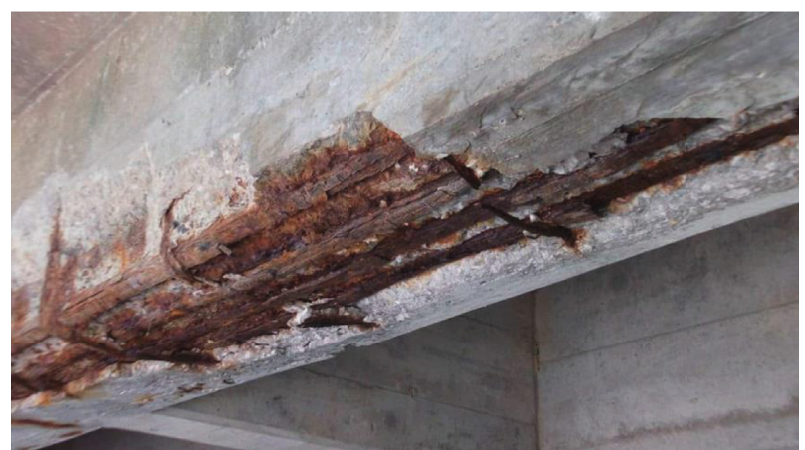

FIGURE 1: Structural performance deterioration of a reinforced concrete (RC) structure caused by reinforcement corrosion [10].

cracks: the corrosion products occupy more space than the original material; hence, they exert pressure on the concrete and crack it. As more corrosion occurs, additional, wider cracks are formed. (4) Spalling of concrete cover: due to loss of the bond between concrete and steel, the concrete starts forming multiple layers of scales and peels off. The sizes of the steel bars are also reduced. (5) Snapping of bars: due to a reduction in the size of the steel bars, they ultimately snap. The main bars also show a considerable reduction in size. (6) Buckling of bars: spalling of the concrete cover and snapping of bars lead to buckling of the main bars. This causes the concrete to bulge and can affect the integrity and life of the RC structures.

The decrease in yield strength resulting from the reduction of the effective area of the steel rebar reduces the tensile force that the steel rebar can resist. Furthermore, the compressive strength of concrete is reduced by spalling of its surfaces. As a result, the entire structure collapses due to the severe structural performance deterioration.

There have also been frequent earthquakes all over the world in recent years. If RC structures in earthquake-prone areas are seriously corroded, this will inevitably affect their seismic performance and safety. As shown in Figure 2, reinforcement corrosion of RC members has a significant impact on the structural performance deterioration (i.e., seismic performance degradation) caused by earthquakes [7], as seen following recent strong earthquakes including the 1995 Kobe Earthquake in Japan $(M=7.3)$, the 1999 Jiji Earthquake in Taiwan $(M=7.3)$, the 1999 Izmit Earthquake in Turkey $(M=7.4)$, the 2008 Sichuan Earthquake in China $(M=8.0)$, the 2010 Chile Earthquake $(M=8.8)$, the 2012 Great East Japan Earthquake $(M=9.0)$, the 2013 Lushan Earthquake in China $(M=7.0)$, and the 2016 Kumamoto Earthquake in Japan $(M=7.0)$.

Even though the intensity of the earthquakes was relatively low, we can see from observations of buildings damaged during the 2004 Niigata-ken Chuetsu Earthquake in Japan $(M=6.8)$, as well as the 2017 Pohang Earthquake in Korea $(M=5.4)$, that corrosion of RC members, including beams and columns, affected failure, as shown in Figure 3. The corrosion of steel leads to a loss of adherence between the reinforcement and concrete over time, in addition to significant losses in cross sections of reinforcement bars. As a result of these losses, reinforcement bars and concrete no longer work in concert, such that the structural element loses a significant amount of its lateral load-carrying capacity.

Therefore, it is of great importance to investigate the effects of seismic performance, in terms of the strength and lateral deformability of corrosion-damaged RC members, on the seismic performance of the entire building system. This will enable us to accurately evaluate the seismic performance of RC structures with corroded members, including beams and columns.

However, current techniques for evaluating the seismic performance of existing RC structures, including those described in the Federal Emergency Management Agency guidelines FEMA 274 [11], FEMA 310 [12], and the Japan Building Disaster Prevention Association standard [13], do not fully take into account the influence of deterioration on the performance of RC members, including corrosion of steel bars.

According to the FEMA 274 [11] and 310 [12] guidelines, the seismic performance of RC buildings should be evaluated by taking the extent of the damage and impact on the capacity of each deteriorated member into account. Deterioration of concrete and reinforcing steel can significantly reduce the lateral strength of concrete members. Site inspection may be required to assess the effects of deterioration of concrete and reinforcing steel. However, assessment of the seismic performance of RC buildings, including the influence of corrosion-damaged members, is simply based on heuristic judgments when following the FEMA 310 guideline, which does not specify any quantitative analysis procedure.

The Japanese standard [13] evaluates the seismic performance of existing RC buildings at each story, and in each direction, using the following seismic capacity index $I_{S}$ : $I_{\mathrm{S}}=E_{\mathrm{O}} \times S_{\mathrm{D}} \times T$. In this equation, $E_{\mathrm{O}}$ is the basic structural performance index calculated with respect to the ultimate horizontal strength, ductility, number of stories, and specific story concerned. $S_{\mathrm{D}}$ (irregularity index) is a subindex of the structural design that is used to modify $E_{\mathrm{O}}$ according to irregularities in the building shape and the distribution of stiffness along the building height. $T$ (time index) is a subindex of the time-dependent deterioration of a building and is used to modify $E_{\mathrm{O}}$ according to deterioration of strength and ductility.

The time index is acquired via site inspections assessing the effects of structural deterioration and aging. This requires an initial inspection, a follow-up inspection, and more detailed additional inspections. During the initial inspection, $T=0.8$ is adopted for buildings that are over 30 years old, while $T=0.9$ is used in cases with significant spalling of the internal finishing. The smallest $T$ values derived from the site inspection should be multiplied by $E_{\mathrm{O}}$ given above. In the follow-up and additional detailed inspections, $T_{i}=0.05$ is adopted if more than one-third of the total members inspected in each direction have corroded reinforcing bars (here, $T_{i}$ is the time index for the story inspected, $i$ ). Finally, on the basis of the weighted $T_{i}$ value of each inspected story, as well as the condition of members including beams and columns, the overall $T$ is used to evaluate the seismic performance of aged RC buildings, which deteriorates with 

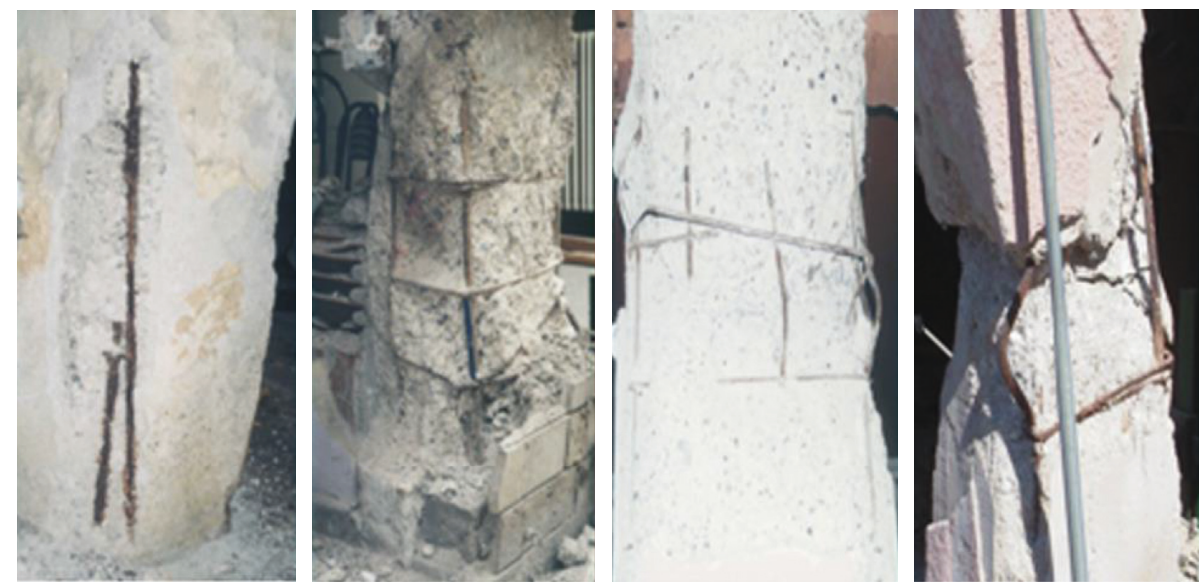

FIgURe 2: Corrosion of RC members damaged during the 1999 Izmit Earthquake in Turkey [7].

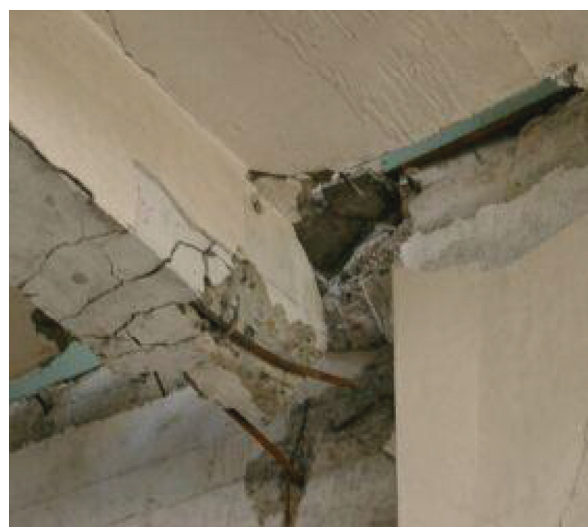

(a)

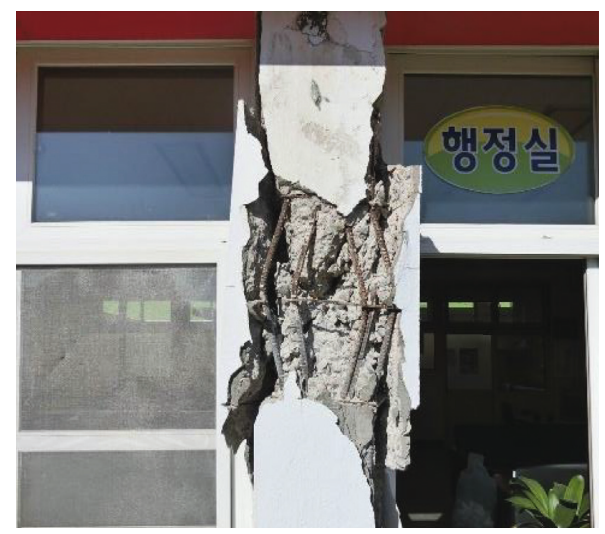

(b)

Figure 3: Corrosion of RC beams and columns damaged during earthquakes. (a) The 2004 Niigata-ken Chuetsu Earthquake in Japan (b) The 2017 Pohang Earthquake in Korea.

corrosion. Compared to the FEMA 274 and 310 guidelines, the Japanese standard can be used to quantitatively evaluate the seismic performance of RC buildings, taking into account the influence of corrosion-damaged members by using $T$ described in the equation. However, the strengthductility degradation relationship between $I_{\mathrm{s}}$ and $T$, which is used to modify $E_{\mathrm{O}}$, is not robust: the Japanese standard is an indirect evaluation methodology.

In previous studies, the seismic performance of $\mathrm{RC}$ structures was mainly assessed based on the strength and deformation capability of the building structure itself, i.e., by using a structural analysis program based on structural drawings and the measured material strength. In this case, the durability reduction factor is calculated directly and quantitatively, taking into account the deterioration of corrosion-damaged $\mathrm{RC}$ members, in addition to an indirect and qualitative assessment, for evaluating the seismic performance of RC structures.

Few studies on seismic performance have taken into account the influence of deterioration of corroded RC members $[7,14]$, and the quantitative reduction factor, based on the strength-deformation capability of corrosion- damaged members relative to unaffected members, has not been determined conclusively. Different surveys, reports, and studies have highlighted that the corrosion of reinforcements is the main cause of deterioration of RC members $[15,16]$.

Therefore, the seismic performance of RC buildings with corrosion-damaged members should be evaluated quantitatively and directly, using a structural performance reduction factor based on the strength-deformation capability, i.e., energy dissipation capability. This will enable accurate evaluation of the seismic performance of RC structures.

The main objective of this research is to propose a practical methodology for evaluating the seismic performance of RC buildings with corrosion-damaged members. A structural performance degradation factor derived from the strength-deformation capability of corroded members is used to evaluate their seismic performance, quantitatively and directly.

Various techniques have been applied to determine the rate and pattern of corrosion in RC structures [17]. One of the most popular techniques is electrochemical measurement, which enables evaluation of corrosion-related parameters 
such as the half-cell potential, concrete resistivity, and corrosion current density [4]. Half-cell potential can be used to determine the corrosion tendency via a reference electrode and a voltmeter. Half-cell potential was used by Pradhan and Bhattacharjee [18] to establish an indicator of corrosion initiation for concrete structures. Due to its simplicity and cost-effectiveness, the corrosion potential measurement method has been widely used for testing the corrosion of reinforcing bars in RC structures [19].

In this study, as a first step toward achieving the main research objective stated above, the effects of reinforcing bar corrosion on the behavior of RC beams and the structural performance degradation factor, which is based on the strength-deformation capability of corrosion-damaged beams, were investigated experimentally.

For this purpose, two types of beams were designed; 8 specimens were used to assess the flexural failure of beams and 8 to assess the shear failure of beams; thus, 16 specimens were used in total. The impressed current technique was applied to assess the accelerated corrosion of the reinforcing bar. For the beam test, we used a four-point bending test under simply supported conditions. The corrosion potential of the reinforcing bar was quantitatively measured based on the half-cell potential, as described previously. We then evaluated the relationship between the performance degradation factor and average potential difference, in terms of voltage, for corrosion-damaged RC beams subjected to flexure and shear.

\section{Experimental Program}

2.1. Materials. We used concrete with a compressive strength of $24.4 \mathrm{MPa}$. Cylindrical specimens were cast at the same time as the beams were manufactured and cured, under the same curing conditions. The compressive strength was measured using cylindrical specimens with dimensions $\phi 100 \times 200 \mathrm{~mm}$ according to ASTM C39/C39M [20]. D16 and D13 deformed reinforcing bars, with a yield strength of $460 \mathrm{MPa}$ and ultimate strength of $495 \mathrm{Mpa}$, were used as longitudinal reinforcing bars and stirrups, respectively. The yield strength and ultimate tensile strength of the reinforcing bars were measured according to ASTM E8/E8M [21].

2.2. Design and Manufacture of Beams. To investigate the effect of corrosion of reinforcing bars on the flexural and shear behaviors of RC beams according to ACI 318 Building Code, two types of beams (16 specimens in total) were designed [22]. As shown in Figure 4, all specimens had a total length of $2,200 \mathrm{~mm}$. The flexural failure type beams had a cross section of $150 \times 250 \mathrm{~mm}$, and the shear failure type beams had a cross section of $200 \times 300 \mathrm{~mm}$. The shear span ratio $(a / d)$ of the shear failure type beam was equal to 3 .

The flexural failure type beam was designed to have longitudinal reinforcements in the form of two D13 bars (tension) and two D10 bars (compression), as well as shear reinforcements in the form of D10 bars at 150 and $100 \mathrm{~mm}$, with a closed-loop stirrup used in the pure bending region and the region between the support and load points. The shear failure type beam was designed to have longitudinal reinforcements of three D13 bars in tension and two D10 bars in compression and shear reinforcements in the form of D10 bars at 150 and $100 \mathrm{~mm}$, with an open-loop stirrup used in the pure bending region and the region between the support and load points. Specimens F-B0 and S-B0 were used as control flexural and shear failure type beam specimens, respectively, without corroded reinforcing bars. Specimens FB-C0 to FB-C7 and SB-C0 to SB-C7 were sequentially degraded by reinforcing bar corrosion. To accelerate the corrosion of the reinforcing bar, a copper wire was embedded at a position $450 \mathrm{~mm}$ from the support, as shown in Figure 4.

We manufactured the beam specimens by assembling a reinforcing bar cage, as shown in Figure 5. Next, the wire for accelerating the corrosion of the reinforcing bar was installed and the reinforcing bar cage was placed within the formwork. Finally, the concrete was placed in the specimen.

2.3. Accelerated Corrosion of Reinforcing Bars. The impressed current technique was adopted to accelerate the corrosion of the reinforcing bar. The beam specimens were placed in a tank 30 days after casting, as shown in Figure 6; 5\% $\mathrm{NaCl}$ solution was used as an electrolyte. The solution level in the tank was adjusted to be approximately $2 \mathrm{~cm}$ below the top surface of the beams, to ensure adequate submersion of all reinforcing bars. Then, the beam specimens were incorporated with a direct current power supply. We used an embedded reinforcing bar as the anode and an external stainless-steel plate as the cathode, to accelerate the corrosion of the reinforcing bar. To simulate structural degradation of the reinforced beam according to the degree of corrosion of the reinforcing bar, the duration of the accelerated corrosion process was included as a test variable. The duration of the accelerated corrosion was increased with increasing beam specimen number to produce the desired sequential structural damage to the beams. The FB-C1 to FB$\mathrm{C} 7$ and SB-C1 to SB-C7 specimens were sequentially removed from the tank and dried out. Then, the potential field on the concrete surface was measured using a half-cell electrode and a high-impedance voltmeter; this voltmeter is one of the devices recommended for measuring corrosion potential in ASTM C876 [23]. The measurement area was covered laterally by six points within $\pm 20 \mathrm{~cm}$ of the center line of the copper wire, which was embedded at a position $450 \mathrm{~mm}$ from the support, and vertically by four points at intervals of $62.5 \mathrm{~cm}$ for the flexural failure type beam and $75 \mathrm{~cm}$ for the shear failure type beam. Thus, there were 24 measurement points ( 4 points in each row and 6 points in each column) in total for each beam.

2.4. Test Program. All beams were subjected to a four-point bending test under conditions of limited support, as shown in Figure 7. The pure bending span between the two loading points was $600 \mathrm{~mm}$ for the flexural failure type beam and $500 \mathrm{~mm}$ for the shear failure type beam. The bending test was performed using a universal testing machine. A monotonic transverse load was applied under load control (loading 


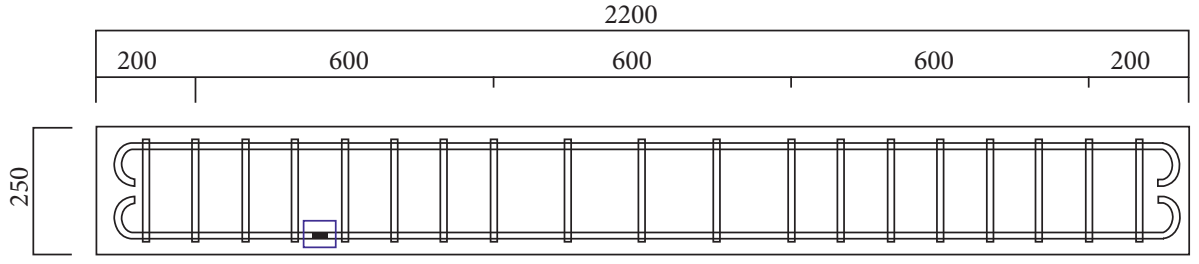

The copper wire was embedded at the position of $450 \mathrm{~mm}$ from support

(a)

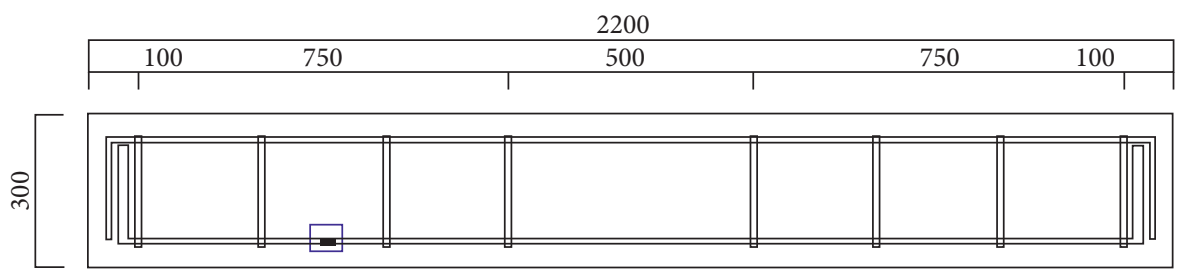

The copper wire was embedded at the position of $450 \mathrm{~mm}$ from support

(b)
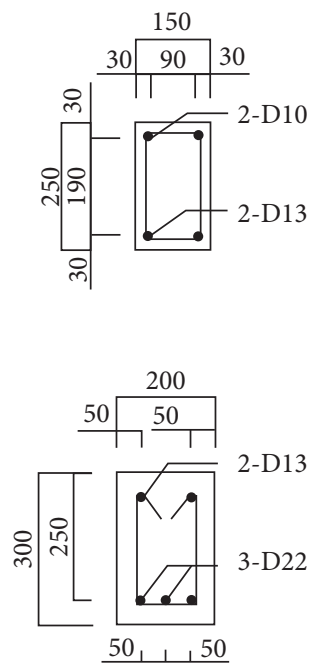

FIgURE 4: Reinforcement details of beams: (a) flexural failure type beam and (b) shear failure type beam.

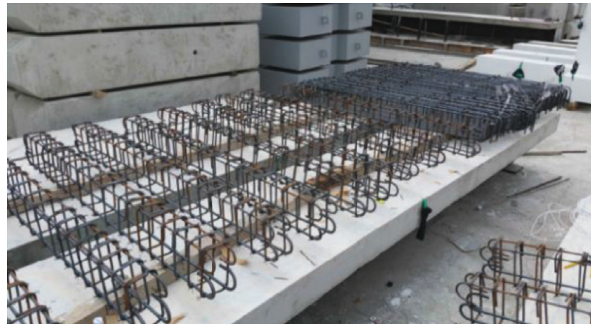

(a)

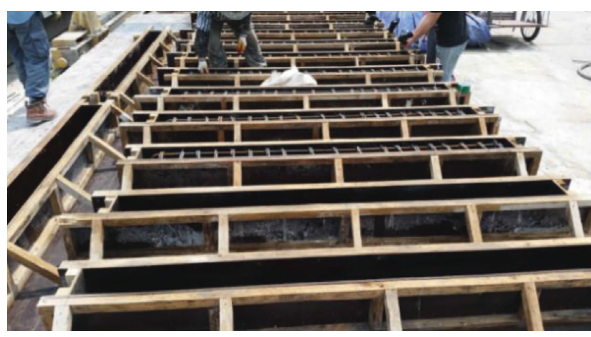

(c)

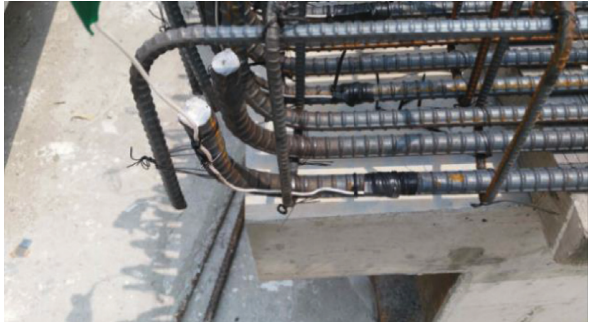

(b)

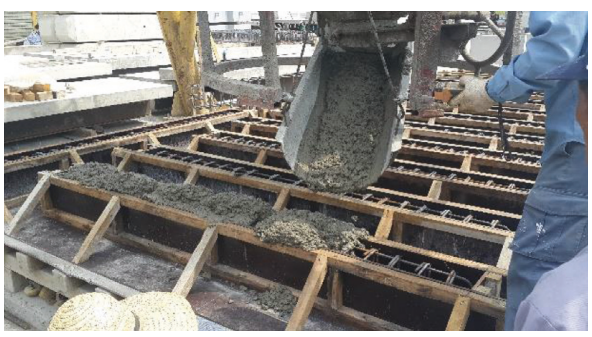

(d)

Figure 5: Beam manufacturing process: (a) assembly of reinforcing bar cage, (b) wire for corrosion of reinforcing bar, (c) installation of reinforcing bar cage, and (d) placement of concrete.

speed of $20 \mathrm{kN} / \mathrm{min}$ ) until the load reached $50 \%$ of the expected maximum load. Then, load was applied under displacement control at a loading speed of $0.7 \mathrm{~mm} / \mathrm{min}$. After the peak load was reached, a further load was applied until the load reached $70 \%$ of the peak load and then released. Deflection at the midspan of each specimen was measured using linear variable differential transducers.

\section{Results and Discussion}

3.1. Half-Cell Potential of Reinforced Concrete Beam. In this study, the corrosion potential of the reinforcing bar is measured by using the CANIN+ corrosion analyzing instrument developed by Proceq [23]. On the basis of the standard specified in ASTM C876 [24], the temperature was set to approximately $28^{\circ} \mathrm{C}$ for the measurement of the corrosion potential of reinforcing steel embedded in concrete. The results of the quantitative measurements (average voltage measured at 24 points) of the corrosion potential of the reinforcing bar in each beam are summarized in Table 1 .

The half-cell potential of the reinforcing bars of the FB$\mathrm{C} 1$ to $\mathrm{FB}-\mathrm{C} 7$ and SB-C1 to SB-C7 specimens increased sequentially, i.e., increased with increased duration of the accelerated corrosion process. Figures 8 and 9 show the halfcell potential map of each measurement point.

According to ASTM C876 [24], if potentials over an area are more positive than $-200 \mathrm{mV}$ CSE (copper sulfate electrode), there is a greater than $90 \%$ probability that no 


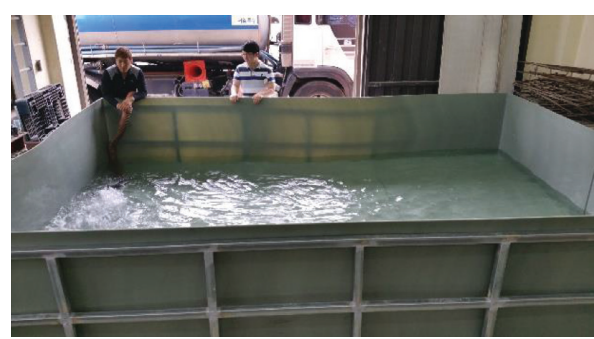

(a)

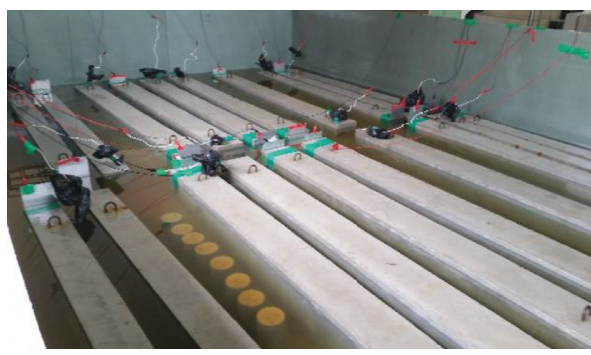

(c)

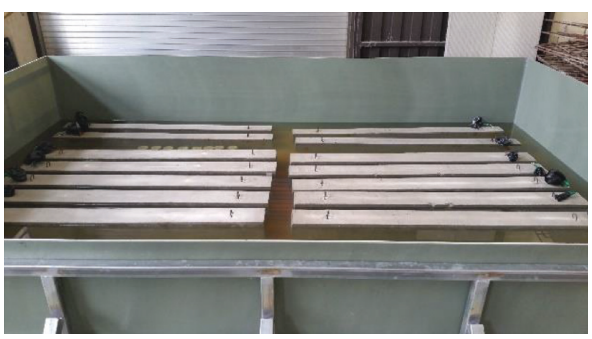

(b)

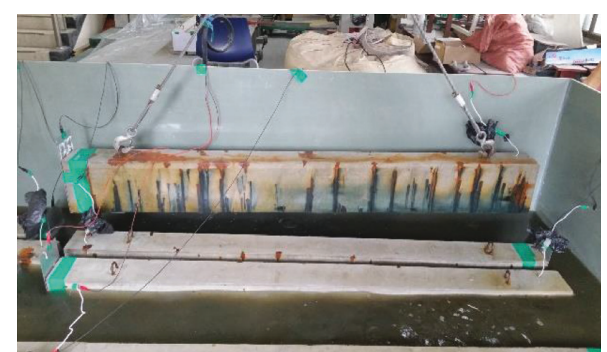

(d)

Figure 6: Accelerated corrosion setup: (a) tank with 5\% $\mathrm{NaCl}$ solution, (b) immersion of beam, (c) accelerated corrosion, and (d) corroded beam.

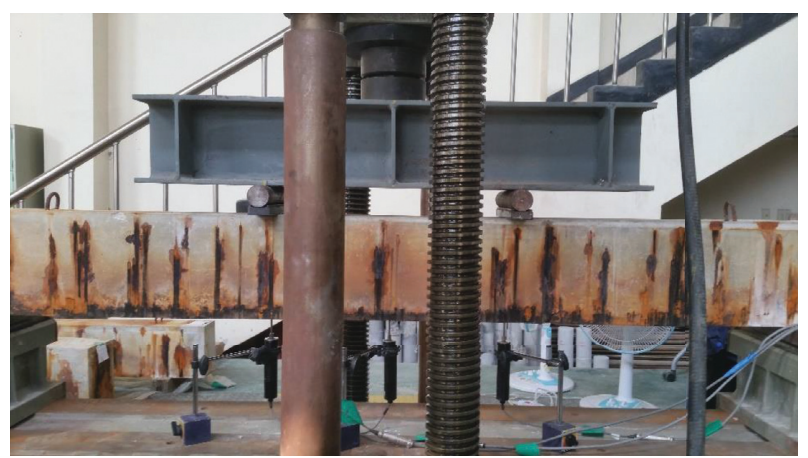

FIgURE 7: Test setup.

TABLE 1: Average potential difference in voltage (unit: $\mathrm{mV}$ CSE).

\begin{tabular}{lcccccccc}
\hline $\begin{array}{l}\text { Type of } \\
\text { beam }\end{array}$ & C0 & C1 & C2 & C3 & C4 & C5 & C6 & C7 \\
\hline $\begin{array}{l}\text { FB-C } \\
\text { series* }\end{array}$ & -63 & -254 & -265 & -280 & -292 & -298 & -374 & -700 \\
$\begin{array}{l}\text { SB-C } \\
\text { series** }\end{array}$ & -171 & -269 & -344 & -551 & -576 & -659 & -700 & -700 \\
\hline * & & & &
\end{tabular}

*Beams controlled by flexure.** Beams controlled by shear.

corrosion of the reinforcing bar is occurring in that area at the time of the measurement. If the potentials over an area are more negative than $-350 \mathrm{mV}$ CSE, there is a greater than $90 \%$ probability that corrosion of the reinforcing bar is occurring in that area at the time of measurement. The halfcell potentials of the control beams, i.e., the FB-C0 and SB$\mathrm{C} 0$ beams, which were not subjected to the accelerated corrosion process, were higher than $-200 \mathrm{mV}$ CSE. On the other hand, other beams with accelerated corrosion processes had half-cell potentials less than -200 mV CSE. We observed that two beams (FB-C6 and FB-C7) in the FB-C series beams had half-cell potentials less than $-350 \mathrm{mV} \mathrm{CSE}$ and five beams (SB-C3 to SB-C7) in the SB-C series beams had half-cell potentials less than $-350 \mathrm{mV}$ CSE.

3.2. Cracking and Failure Pattern. Figure 10 shows the cracking patterns at the midspan of the flexural failure type beams. In the case of the FB-C0 beam, the initial cracking took place near the midspan of the beam at a load of $10.4 \mathrm{kN}$, and the corresponding deflection at the midspan was $0.49 \mathrm{~mm}$. The cracks spread from the midspan to the support with a crack spacing of $50 \sim 150 \mathrm{~mm}$. The reinforcing bar started to yield at a load of $65.0 \mathrm{kN}$ and the corresponding deflection was $7.0 \mathrm{~mm}$. After the yield load, the width of the cracks increased significantly until the specimen failed. Final failure of the beam occurred due to crushing of the concrete at the top of the beam, with cracks reaching the upper parts of the beams.

Overall, the flexural behavior of the FB-C0 specimen was similar to the typical behavior of underreinforced beams. The FB-C1 to FB-C7 beams, which were each corroded to varying degrees, exhibited similar failure patterns to the FB$\mathrm{C} 0$ beam. However, we observed that the amount of rust increased as we increased the duration of the accelerated corrosion, which is quantitatively represented by the halfcell potential. The deflection corresponding to the ultimate load varied significantly according to the duration of accelerated corrosion, between 80 and $110 \mathrm{~mm}$.

Figure 11 shows the cracking patterns at midspan for the shear failure type beams. In the case of the SB-C0 beam, the crack started near the midspan of the beam at a load of $22.0 \mathrm{kN}$, and the corresponding deflection of the beam at the midspan was $0.52 \mathrm{~mm}$. A diagonal crack was observed in the right part of the beam at a load of $90.2 \mathrm{kN}$ (deflection: 


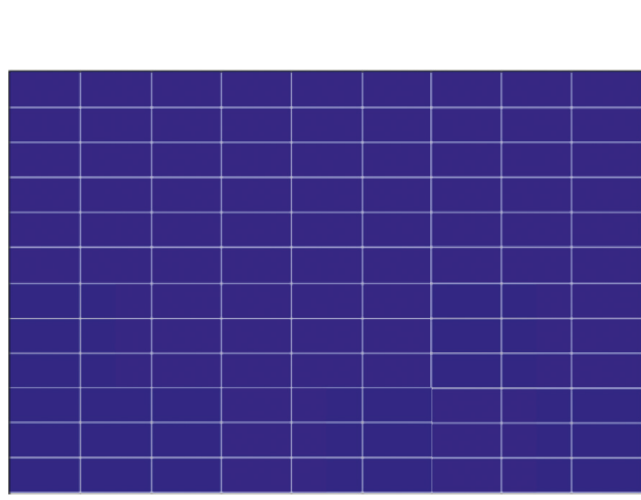

(a)

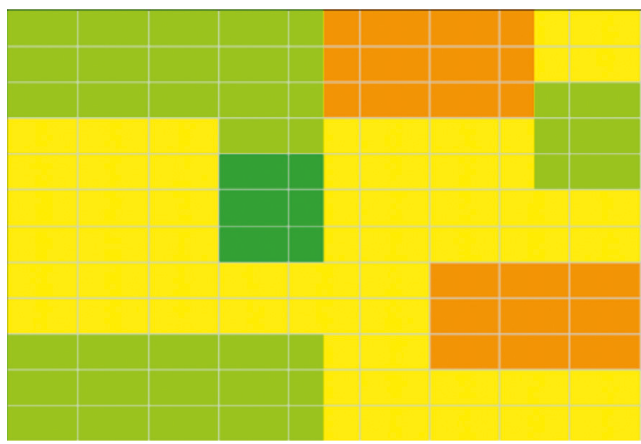

(c)

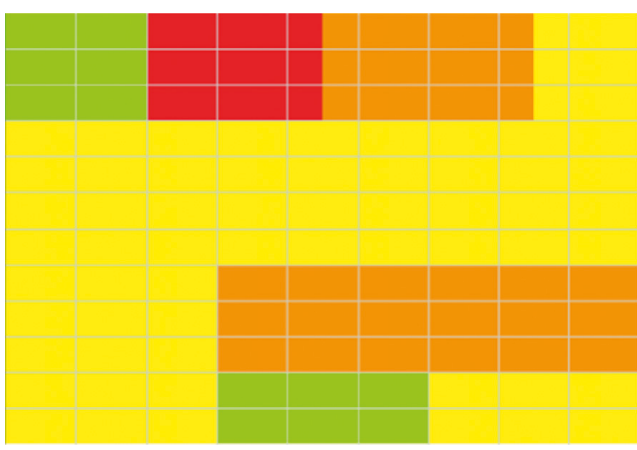

(e)

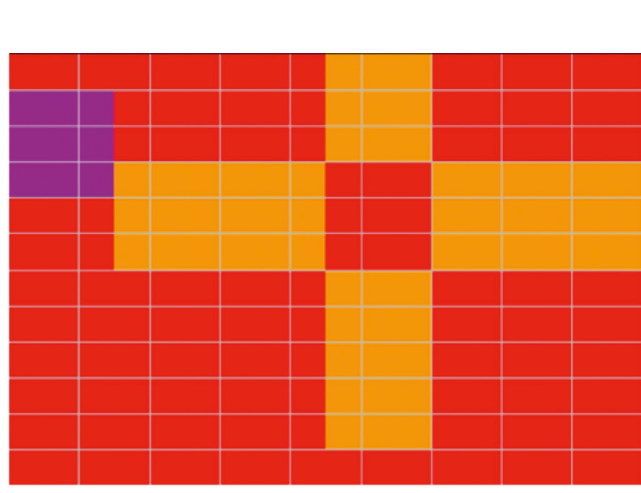

(g)
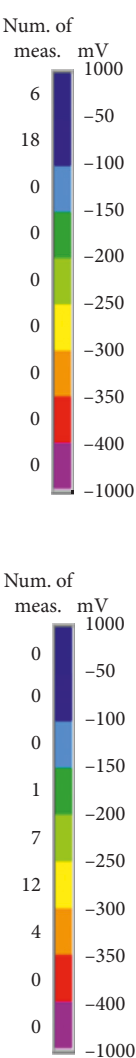

$-1000$
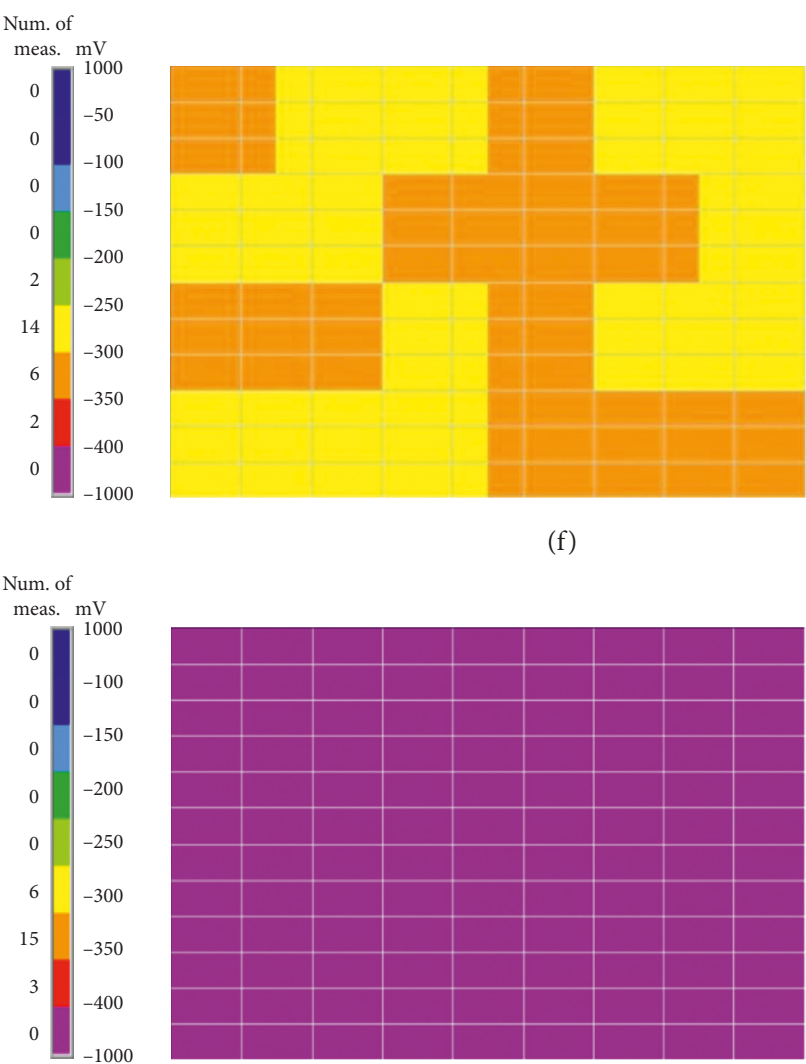

(f)
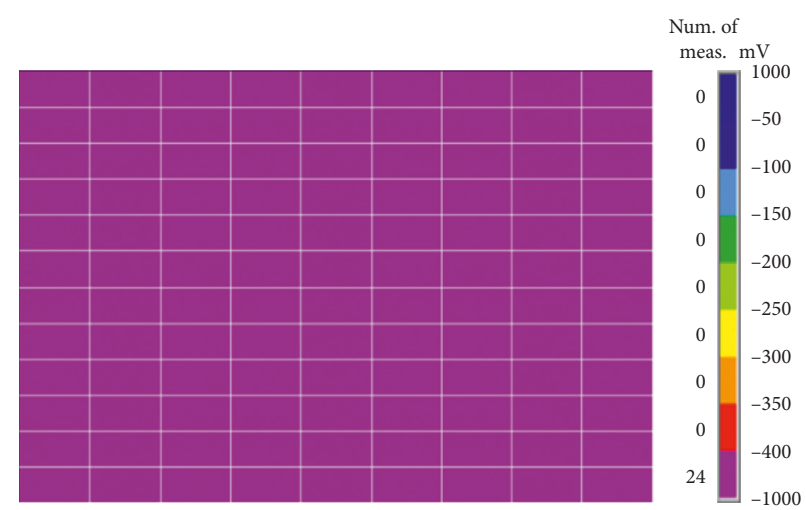

(h)

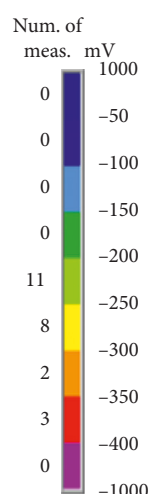

(b)

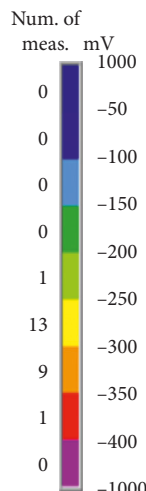

(d)

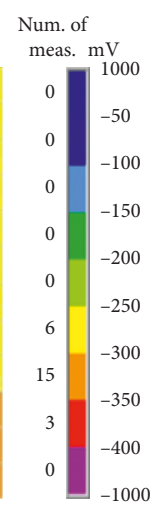

$-1000$
Figure 8: Potential map of beams controlled by flexure: (a) FB-C0, (b) FB-C1, (c) FB-C2, (d), FB-C3, (e) FB-C4, (f) FB-C5, (g) FB-C6, and (h) FB-C7. 


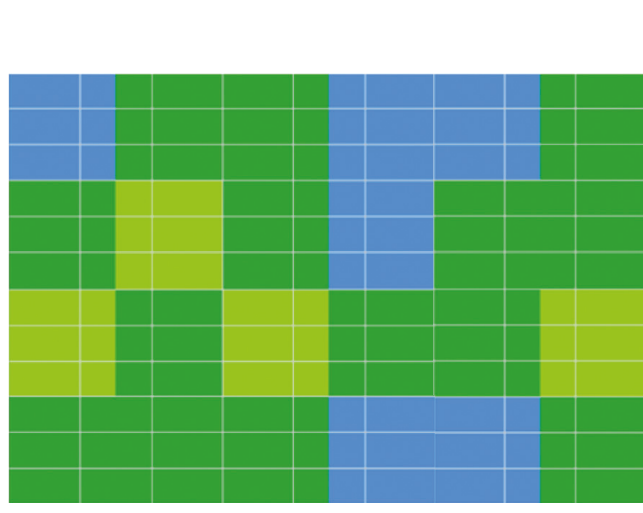

(a)

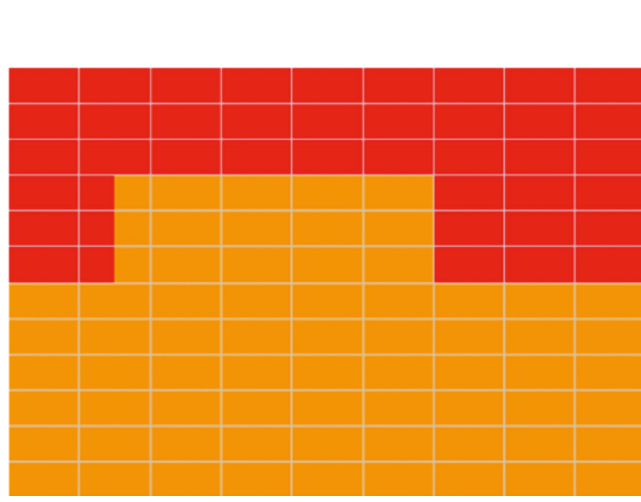

(c)

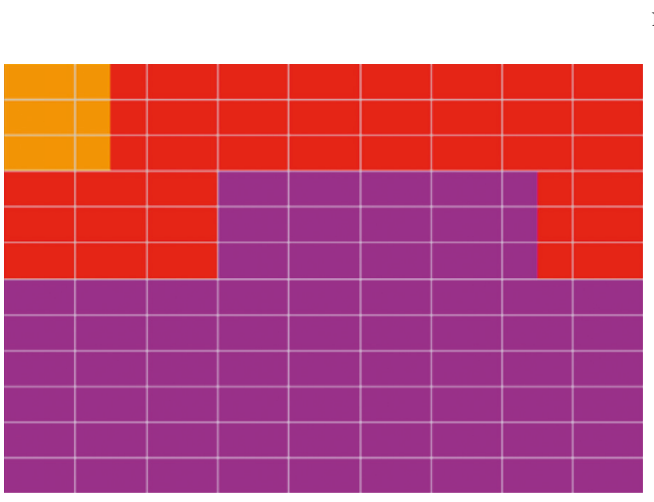

(e)

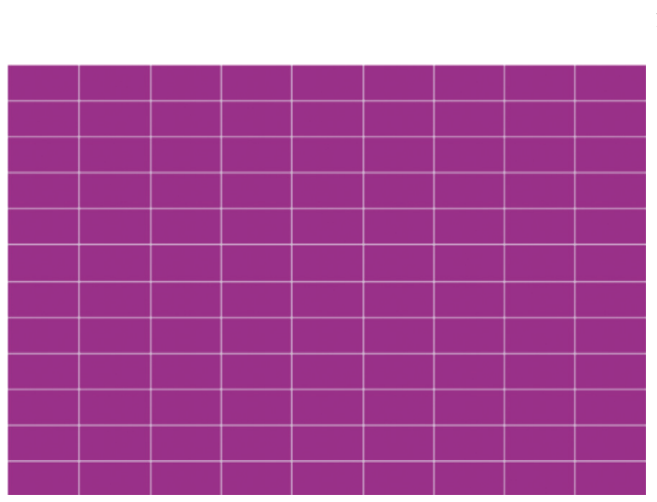

(g)
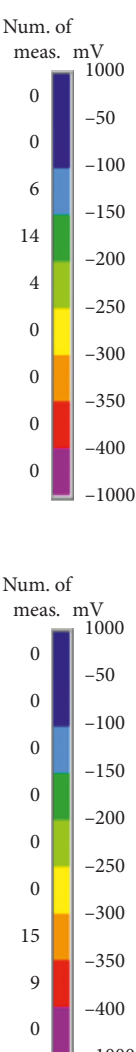

meas. $\mathrm{mV}$

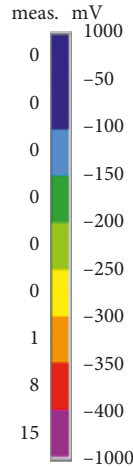

$-1000$

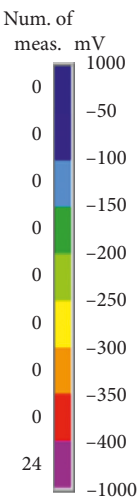

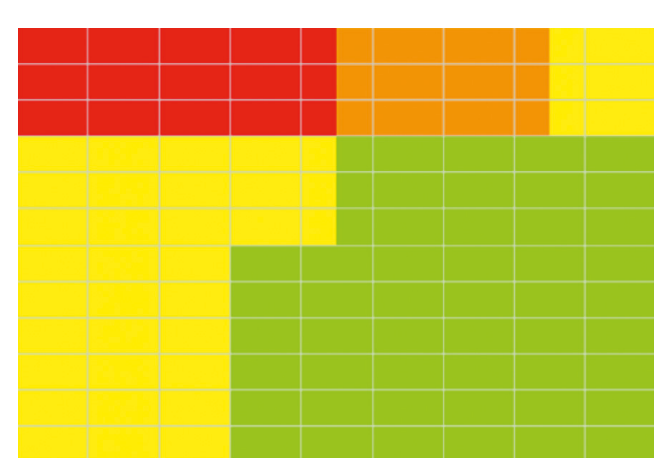

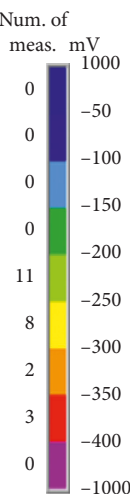

(b)
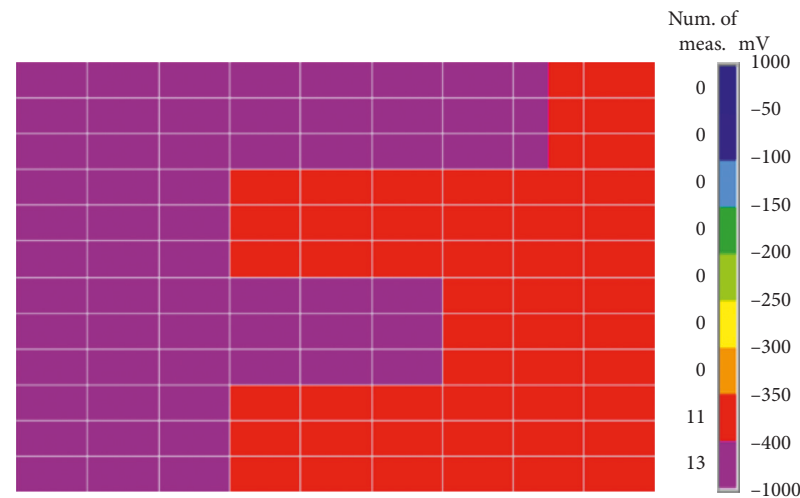

(d)

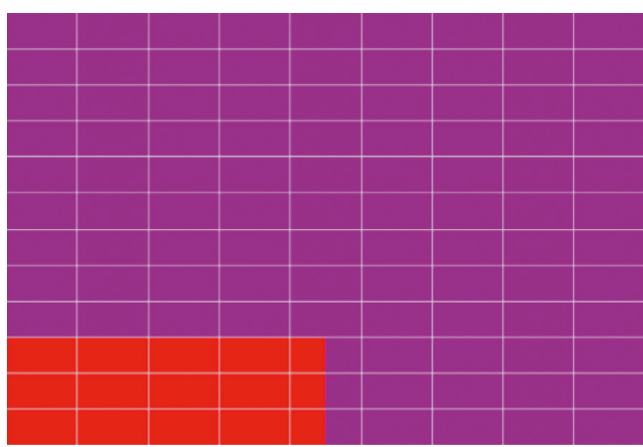

Num. of

meas. $\mathrm{mV}$

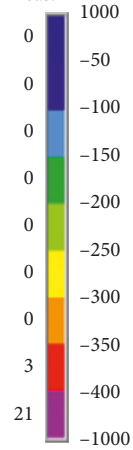

(f)

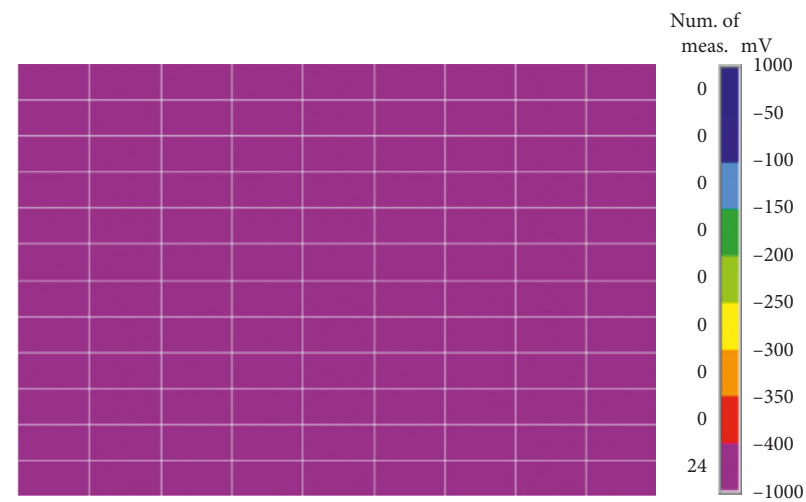

(h)

Figure 9: Potential map of beams controlled by shear: (a) SB-C0, (b) SB-C1, (c) SB-C2, (d) SB-C3, (e) SB-C4, (f) SB-C5, (g) SB-C6, and (h) SB-C7. 


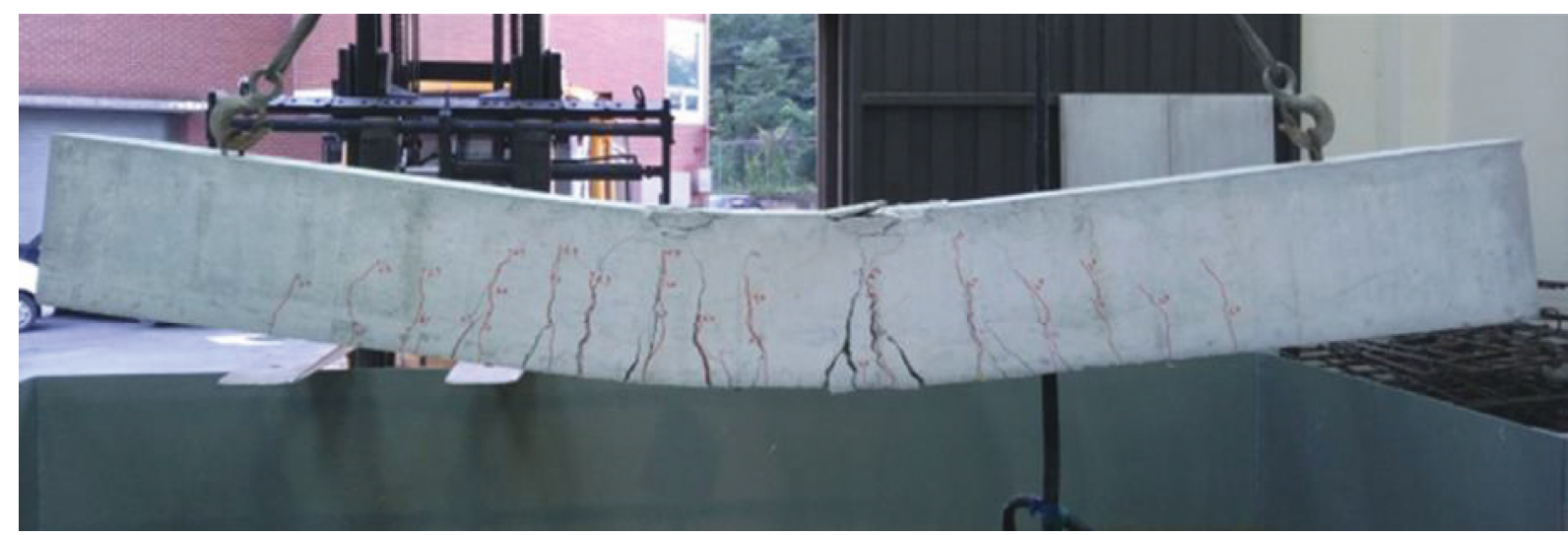

(a)

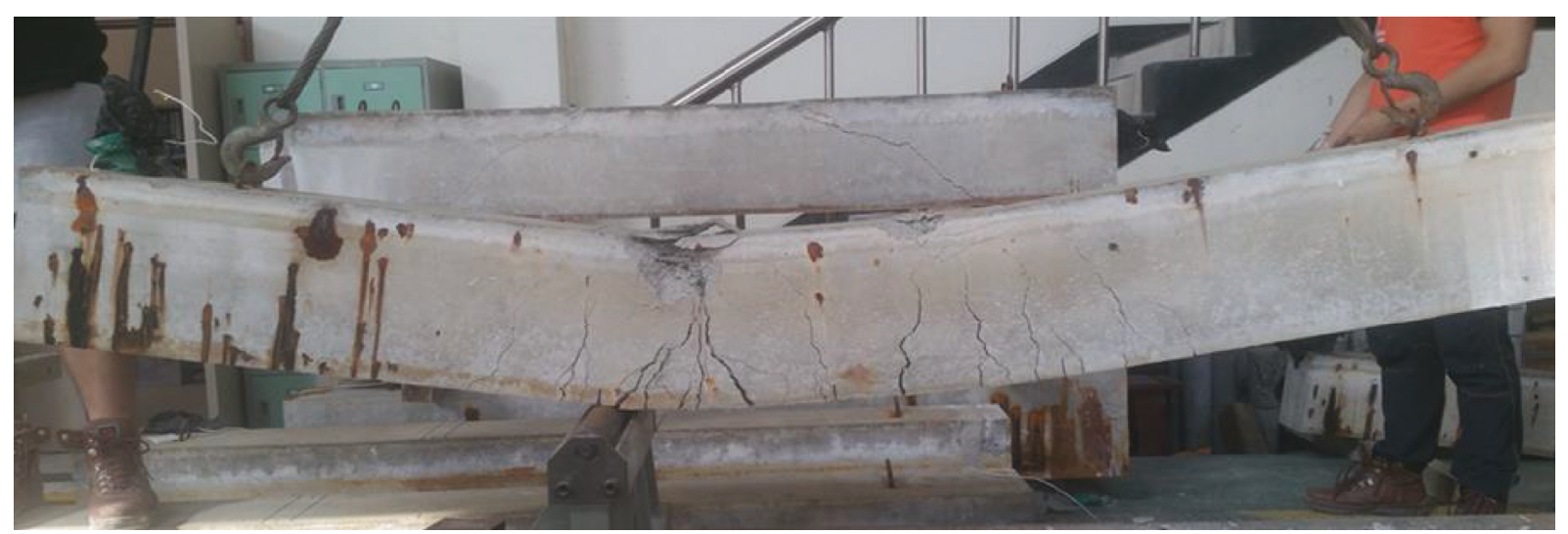

(b)

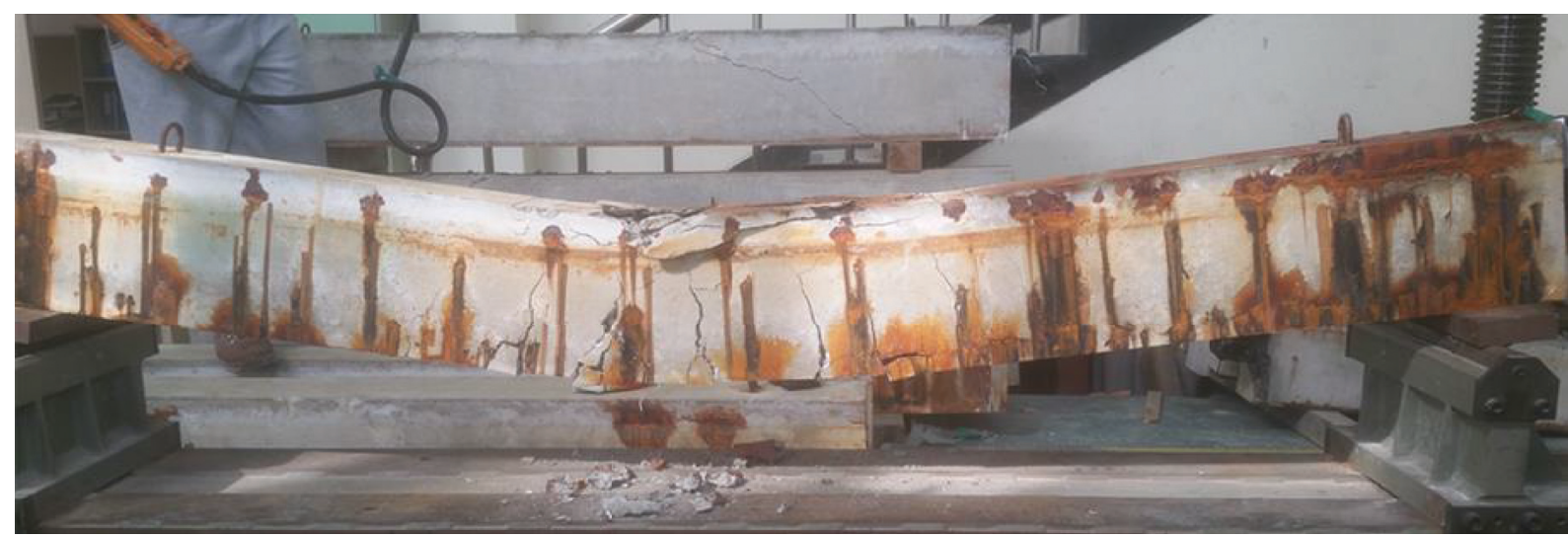

(c)

Figure 10: Cracking and failure patterns of flexural failure type beams: (a) FB-C0 beam, (b) FB-C4 beam, and (c) FB-C7 beam.

$2.67 \mathrm{~mm})$. The number and width of cracks increased until the maximum load $(182 \mathrm{kN})$ was reached. After the ultimate load, we observed a fast load drop as a diagonal crack reached the top surface. Overall, the behavior of the SB-C0 specimen was relatively similar to the typical brittle behavior of shear failure beams. The SB-C1 to SB-C7 beams, which were each corroded to different extents, exhibited similar cracking strengths and corresponding deflections and similar failure patterns to the SB-C0 beam. However, we also observed that the amount of rust increased as we increased the duration of accelerated corrosion. The ultimate load and maximum deflection varied significantly with the duration of the accelerated corrosion.

3.3. Load and Deflection. Figure 12 shows the load and deflection curves of the flexural failure type (FB-C series) beams and the shear failure type (SB-C series) beams, respectively. The FB-C series beams exhibited similar behavior prior to their ultimate state. The load and deflection values of each beam at the initial cracking of the concrete, the yielding of tensile reinforcement, and the ultimate load, ductility 


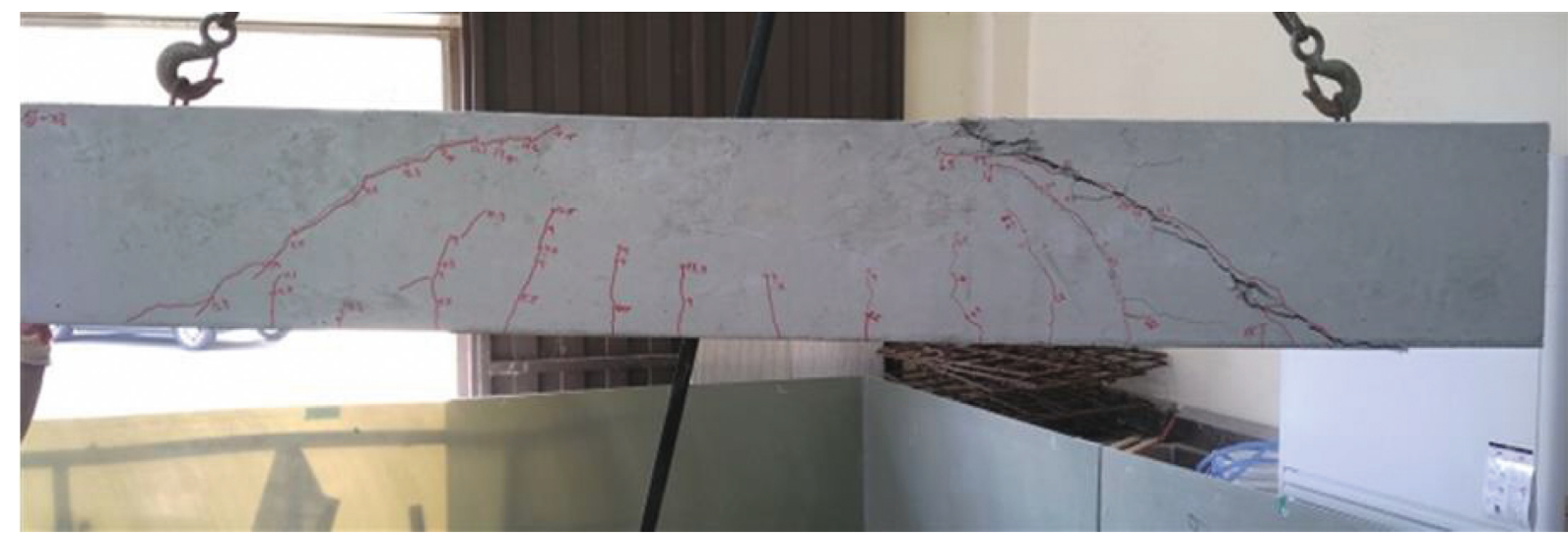

(a)

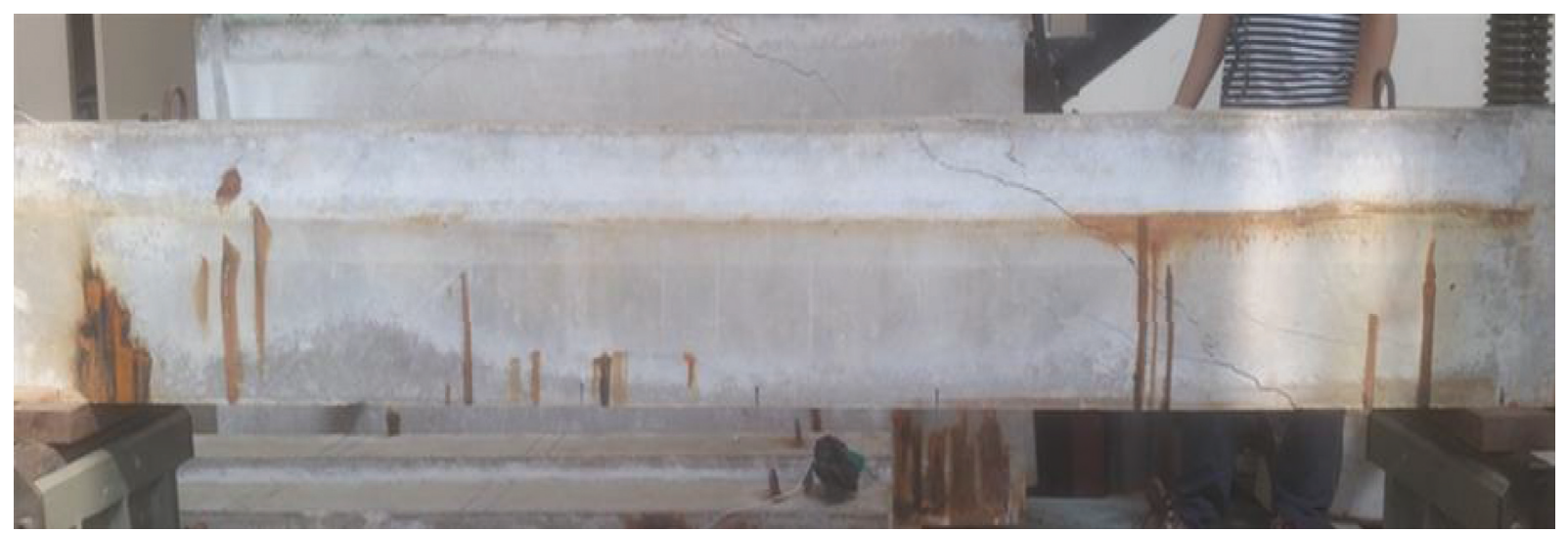

(b)

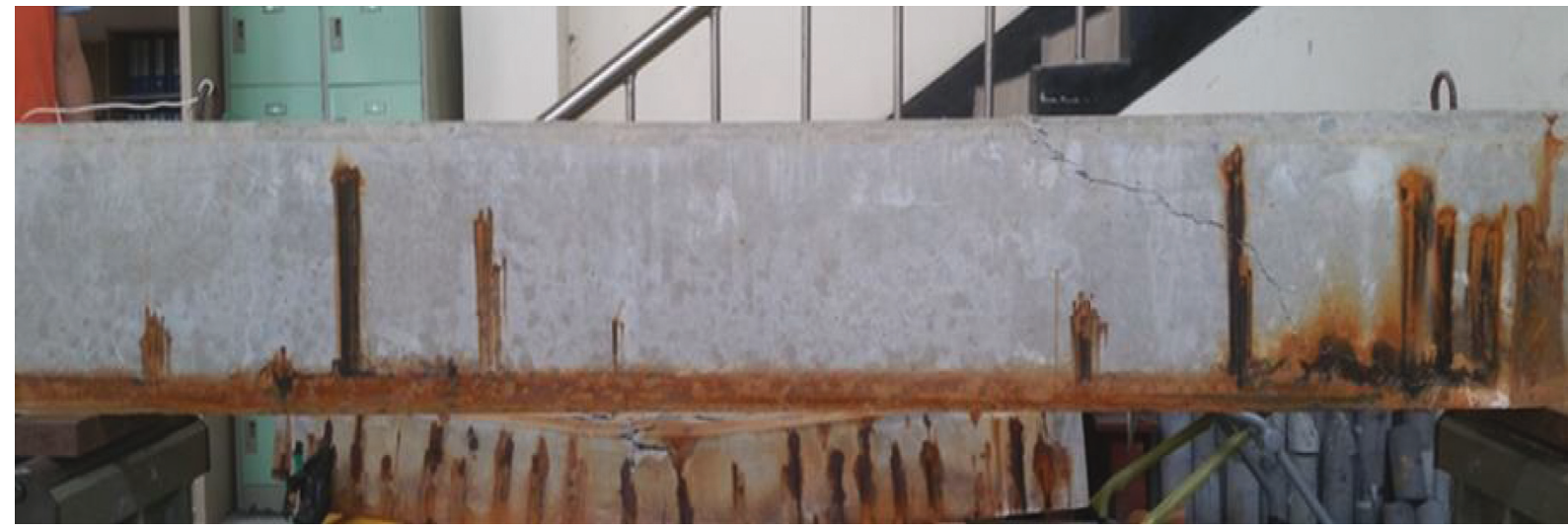

(c)

FiguRE 11: Cracking and failure patterns of shear failure type beams: (a) SB-C0 beam, (b) SB-C4 beam, and (c) SB-C7 beam.

ratio, dissipated energy, and performance degradation factor are summarized in Table 2. The performance degradation factor $(\phi)$ was defined by the following equation:

$$
\phi=\frac{E_{r}}{E_{t}},
$$

where $E_{t}$ and $E_{r}$ are the absorbable energy capacity before and after corrosion of the reinforcing bar, respectively.

All flexural failure type beams (FB-C series) exhibited similar cracking loads and deflections, ranging from 10.3 to $13.1 \mathrm{kN}$ and 0.44 to $0.59 \mathrm{~mm}$, respectively, and similar yield loads and deflections, ranging from 62.6 to $63.2 \mathrm{kN}$ and 6.21 to $6.48 \mathrm{~mm}$, respectively. At the ultimate state, the difference between the ultimate loads was less than $11.7 \%$. The maximum difference in displacement corresponding to the ultimate loads and degradation factor was $34.1 \%$ and $30.1 \%$, respectively.

According to these test results, we concluded that the corrosion of reinforcing bars has a negative influence on the deformation corresponding to the ultimate load and energy dissipation capacity, which can be expressed as the degradation factor. The effect of corrosion on the flexural behavior of the beams prior to the ultimate state and ultimate load was 


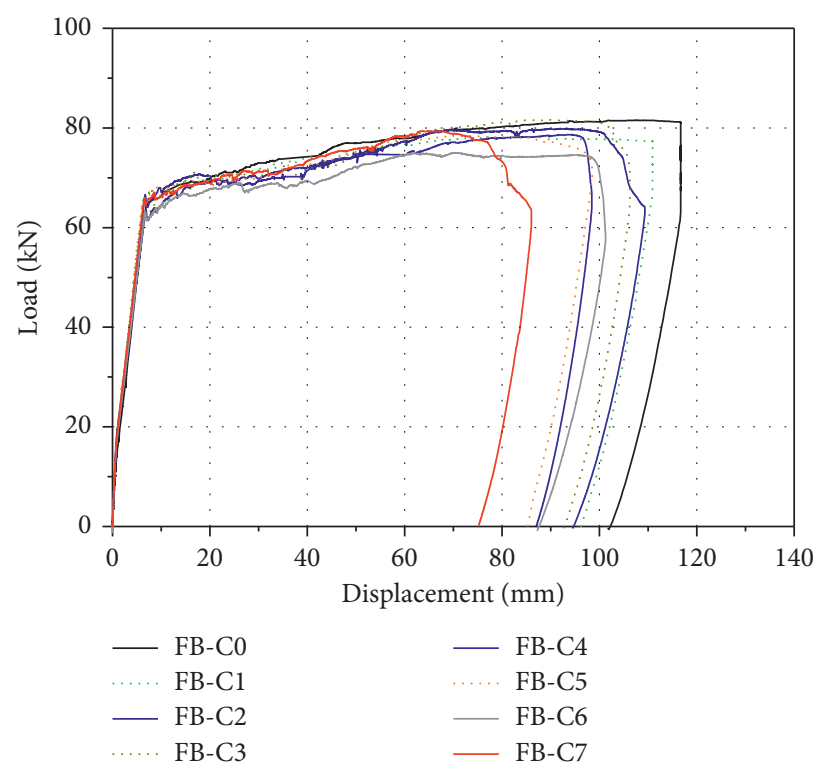

(a)

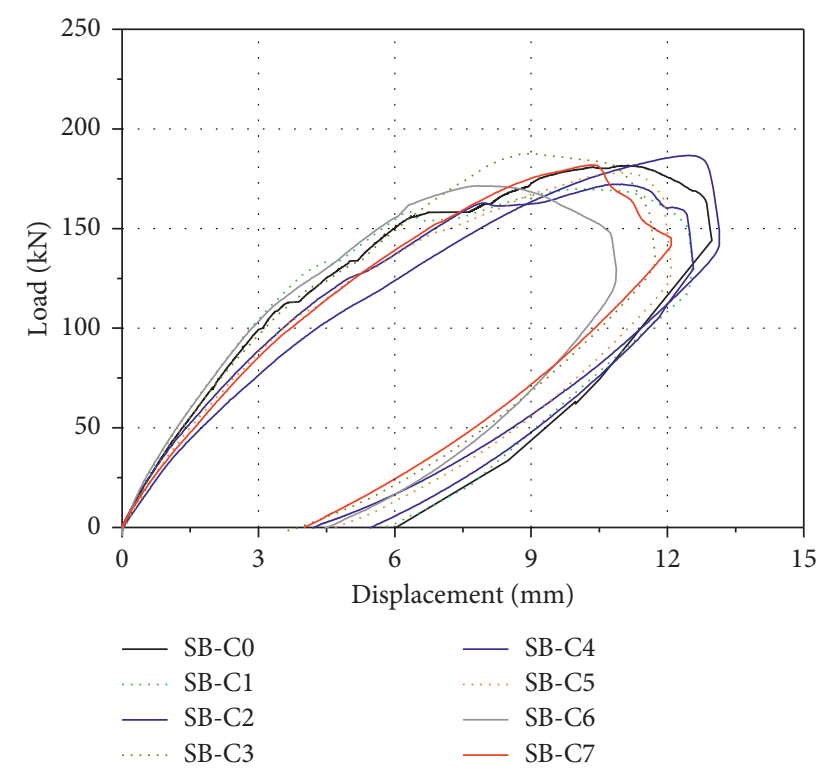

(b)

Figure 12: Load and deflection curves at the midspan of beams: (a) flexural failure type beams and (b) shear failure type beam.

TABLE 2: Test results for each specimen.

\begin{tabular}{|c|c|c|c|c|c|c|c|c|}
\hline \multirow{2}{*}{ Beam } & \multicolumn{2}{|c|}{ First cracking } & \multicolumn{2}{|c|}{ Reinforcement yielding } & \multicolumn{2}{|c|}{ Ultimate } & \multirow{2}{*}{ Dissipation energy (kN-mm) } & \multirow{2}{*}{$\phi^{*}(\%)$} \\
\hline & Load $(\mathrm{kN})$ & Deflection $(\mathrm{mm})$ & Load $(\mathrm{kN})$ & Deflection $(\mathrm{mm})$ & Load $(\mathrm{kN})$ & Deflection $(\mathrm{mm})$ & & \\
\hline $\mathrm{FB}-\mathrm{C} 0$ & 10.3 & 0.49 & 65.0 & 7.00 & 81.6 & 116.7 & 8,298 & 100.0 \\
\hline $\mathrm{FB}-\mathrm{C} 1$ & 12.5 & 0.50 & 66.5 & 6.68 & 78.9 & 100.9 & 7,521 & 90.6 \\
\hline $\mathrm{FB}-\mathrm{C} 2$ & 13.1 & 0.59 & 66.6 & 6.54 & 77.4 & 110.9 & 7,639 & 92.1 \\
\hline FB-C3 & 12.7 & 0.55 & 62.6 & 6.48 & 80.7 & 101.4 & 7,404 & 89.2 \\
\hline $\mathrm{FB}-\mathrm{C} 4$ & 10.7 & 0.46 & 63.4 & 6.90 & 78.4 & 95.6 & 6,683 & 80.5 \\
\hline FB-C5 & 10.8 & 0.44 & 65.0 & 6.21 & 72.0 & 98.7 & 6,659 & 80.3 \\
\hline FB-C6 & 10.6 & 0.44 & 63.2 & 6.75 & 74.3 & 97.4 & 6,651 & 80.2 \\
\hline FB-C7 & 12.1 & 0.50 & 66.0 & 6.55 & 77.2 & 76.9 & 5,797 & 69.9 \\
\hline SB-C0 & 22.0 & 0.52 & 158.3 & 7.04 & 181.9 & 11.3 & 1,301 & 100.0 \\
\hline SB-C1 & 21.9 & 0.48 & 89.6 & 2.25 & 169.8 & 10.0 & 1,267 & 97.3 \\
\hline SB-C2 & 18.0 & 0.39 & 93.9 & 3.24 & 172.3 & 11.0 & 1,178 & 90.5 \\
\hline SB-C3 & 18.3 & 0.45 & 74.0 & 2.14 & 187.7 & 9.0 & 1,121 & 86.2 \\
\hline SB-C4 & 16.0 & 0.50 & 79.6 & 3.16 & 186.7 & 12.5 & 1,090 & 83.7 \\
\hline SB-C5 & 18.1 & 0.50 & 106.7 & 3.82 & 178.1 & 11.1 & 1,101 & 84.6 \\
\hline SB-C6 & 23.7 & 0.49 & 98.3 & 2.79 & 171.4 & 7.8 & 1,056 & 81.1 \\
\hline SB-C7 & 19.3 & 0.51 & 82.5 & 2.88 & 181.9 & 10.3 & 995 & 76.4 \\
\hline
\end{tabular}

*Performance degradation factor.

less significant. The energy dissipation of the FB-C series beams decreased as we increased the half-cell potential. The decrease in energy dissipation of FB-C7, which exhibited a maximum absolute half-cell potential, was up to $30.1 \%$ compared to that of the FB-C0 control beam. This was attributed to the decrease in effective area of the reinforcing bar due to corrosion $[2,4,7,15,16]$.

As expected, all SB-C series beams exhibited brittle failure behavior compared to the FB-C series beams. Furthermore, larger variations in the cracking, yielding, and ultimate state of beams with respect to the reinforcing bar corrosion were observed than in the case of the FB-C series beams. The maximum decrease in the first cracking load, reinforcement yielding load, and ultimate load was $27.4 \%$, $53.3 \%$, and $10.3 \%$, respectively. Although large decreases in the first cracking load and reinforcement yielding load were observed compared to the FB-C series beams, the effect of reinforcing bar corrosion on the ultimate state was less significant. The energy dissipation of the SB-C series beams also decreased with increasing half-cell potential. The energy dissipation of SB-C7, which also exhibited a maximum absolute half-cell potential, was $23.6 \%$ lower than that of the SB-C0 control beam.

Figure 13 shows the relationship between the performance degradation factor and average potential difference. We applied empirical regression models to derive the 


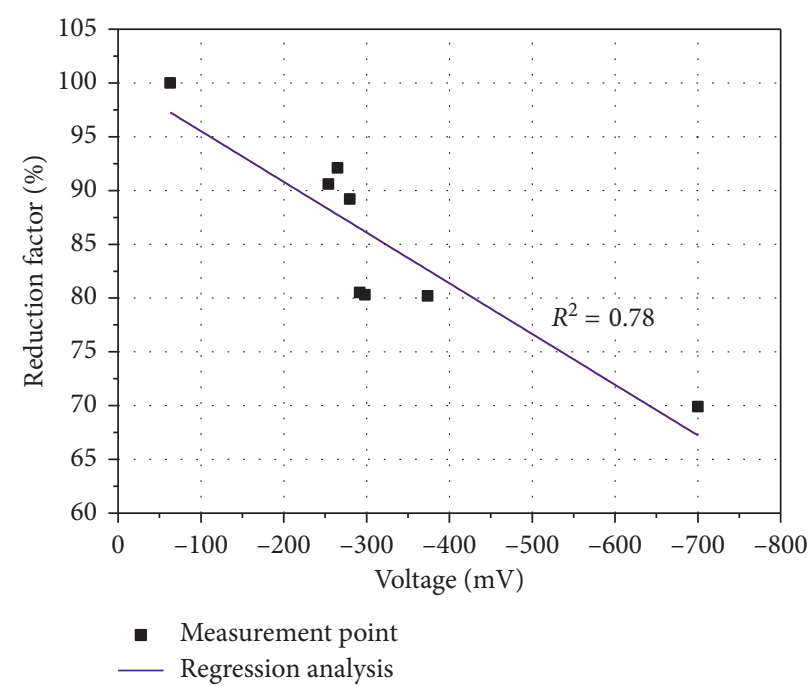

(a)

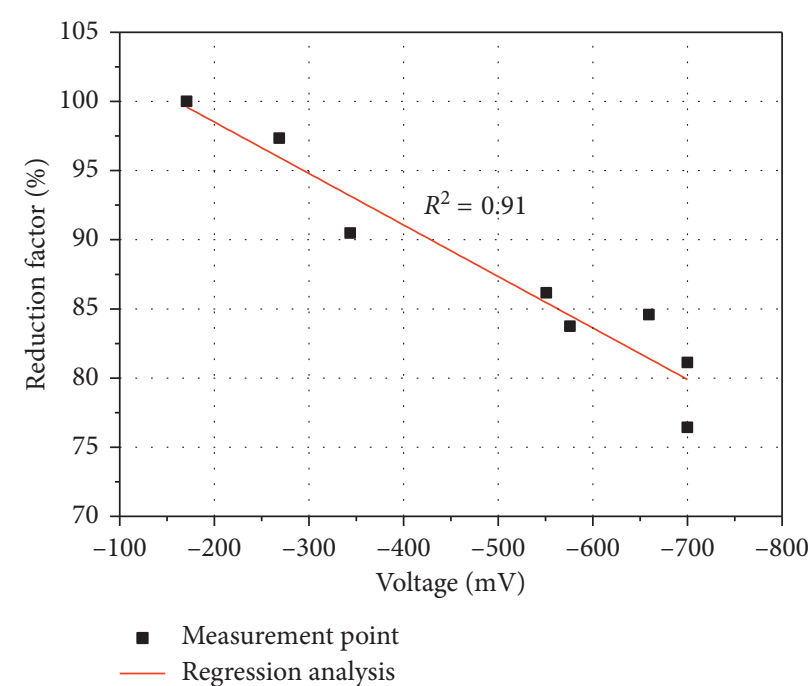

(b)

FIGURE 13: Relationship between the performance degradation factor and average potential difference in terms of voltage: (a) flexural failure type beams and (b) shear failure type beam.

quantitative relationship between the performance degradation factor and the average potential difference. As shown in Figure 13, we detected a relatively strong correlation between the performance degradation factor and average potential difference. The coefficients of determination $\left(R^{2}\right)$ of the FB-C series beams and SB-C series beams were 0.78 and 0.91 , respectively.

It is well known, on the other hand, that the value of the half-cell potential measurement cannot be used to estimate the structural properties of $\mathrm{RC}$ members because the test results of half-cell potential measurements are affected by the degree of humidity in the concrete, oxygen content near the reinforcement, microcracks, etc. [25]. The results shown in Figure 13 indicate that the potential difference measured using the half-cell method can serve as one of the parameters for indicating relative structural degradation, as long as the same environmental conditions are used.

By using relationship between the performance degradation factor and average potential difference in terms of voltage, the energy absorption capacity (the reduction factor in Figure 13), calculated based on strength-deformation capability of corrosion-damaged RC members, can be evaluated. The result of each energy absorption capacity of corrosiondamaged members can be utilized for predicting the seismic capacity of entire RC buildings. For instance, for the corrosion-damaged members, the basic structural performance index $\left(E_{\mathrm{O}}\right)$ calculated with respect to the ultimate horizontal strength and ductility for each member can be quantitatively and directly calculated when applying the Japanese standard for seismic evaluation of entire RC buildings.

\section{Conclusions}

We experimentally investigated the effect of the corrosion of reinforcing bars on the flexural and shear behaviors of RC beams and proposed a relationship between the half-cell potential of corroded reinforcing bars and structural performance degradation behavior of RC beams. The following conclusions can be drawn from our experimental results:

(1) The flexural and shear behaviors of the control beams were generally similar to the typical behaviors of underreinforced beams. The shear and flexural beams, corroded to varying degrees among specimens, exhibited similar failure patterns to the control beam. However, we also observed that the amount of rust increased, and the ultimate load and maximum deflection varied significantly, with the duration of accelerated corrosion.

(2) Based on the test results on the flexural behavior of beams, we concluded that the corrosion of reinforcing bars negatively influences the deformation corresponding to the ultimate load and energy dissipation capacity, which we expressed as the degradation factor. The effect of corrosion on reinforcing bars prior to the ultimate state and ultimate load was less significant. The energy dissipation of the flexural beams decreased with increasing half-cell potential. The energy dissipation of the specimen that exhibited the maximum absolute half-cell potential decreased by up to $30.1 \%$ compared to that of the control beam.

(3) All of the beams controlled by shear exhibited brittle failure behavior compared to those controlled by flexure, and larger variations in the cracking, yielding, and ultimate state of the former beams according to the reinforcing bar corrosion were observed than in the case of the flexural beams. The energy dissipation of the shear beams also decreased with increasing halfcell potential, just as in the case of the flexural beams. The decrease in energy dissipation of the specimen with the maximum absolute half-cell potential was $23.6 \%$ lower than that of the control beam. 
(4) We detected a relatively strong correlation between the performance degradation factor and average potential difference, and the coefficients of determination $\left(R^{2}\right)$ of the flexural beams and shear beams were 0.78 and 0.91 , respectively. The potential difference measured using the half-cell method can be used as an indicator of relative structural degradation if the environmental conditions are held constant. On the basis of relationship between the performance degradation factor and average potential difference, the energy absorption capacity, calculated based on strength-deformation capability of corrosion-damaged RC members, can be evaluated. The result of each energy absorption capacity of corrosion-damaged members can be utilized for predicting the seismic capacity of entire RC buildings.

(5) The main objective of this research is to propose a practical methodology for evaluating the seismic performance of RC buildings with corrosion-damaged members. A structural performance degradation factor derived from the energy absorption capacity, calculated based on strength-deformation capability of corroded members, is used to evaluate their seismic performance, quantitatively and directly. As a first step toward achieving the main research objective, in this study, the effects of reinforcing bar corrosion on the behavior of RC beams and the structural performance degradation factor were investigated experimentally. The beam is not the lateral resisting member like the column. Therefore, the results investigated in this research could not be directly used for evaluating the seismic capacity of entire RC building. In order to propose a robust practical methodology for evaluating the seismic performance of RC buildings with corrosion-damaged members, the seismic performance degradation factor of lateral load resisting systems such as columns should be experimentally derived for further research, together with analytical investigations such as finite element analysis.

\section{Data Availability}

All datasets generated during this study are available from the corresponding author on reasonable request.

\section{Conflicts of Interest}

The authors declare that they have no conflicts of interest.

\section{Acknowledgments}

This research was supported by the National Research Foundation of Korea (2017R1A2B4008983 and 2015R1A5A1037548), funded by the Ministry of Education and the Ministry of Science and Information and Communications Technology, and by the Korea Agency for Infrastructure Technology Advancement grant (19CTAPC153033-01-000000) funded by the Ministry of Land, Infrastructure, and Transport.

\section{References}

[1] C. M. Hansson, "Comments on electrochemical measurements of the rate of corrosion of steel in concrete," Cement and Concrete Research, vol. 14, no. 4, pp. 574-584, 1984.

[2] H. S. Lee, F. Tomosawa, and T. Noguchi, "Effects of rebar corrosion on the structural performance of singly reinforced beams," Durability of Building Materials and Components, vol. 7, no. 1, pp. 571-580, 1996.

[3] D. M. Frangopol, K.-Y. Lin, and A. C. Estes, "Reliability of reinforced concrete girders under corrosion attack," Journal of Structural Engineering, vol. 123, no. 3, pp. 286-297, 1997.

[4] A. Shamsad, "Reinforcement corrosion in concrete structures, its monitoring and service life prediction-a review," Journal of Cement and Concrete Composites, vol. 25, no. 4-5, pp. 459-471, 2003.

[5] H.-W. Song, H.-B. Shim, A. Petcherdchoo, and S.-K. Park, "Service life prediction of repaired concrete structures under chloride environment using finite difference method," $\mathrm{Ce}$ ment and Concrete Composites, vol. 31, no. 2, pp. 120-127, 2009.

[6] H.-S. Lee and Y.-S. Cho, "Evaluation of the mechanical properties of steel reinforcement embedded in concrete specimen as a function of the degree of reinforcement corrosion," International Journal of Fracture, vol. 157, no. 1-2, pp. 81-88, 2009.

[7] M. Dogan, "Corrosion failure in concrete reinforcement to damage during seismic," Engineering Failure Analysis, vol. 56, pp. 275-287, 2015.

[8] Z. Yu, Y. Chen, P. Liu, and W. Wang, "Accelerated simulation of chloride ingress into concrete under drying-wetting alternation condition chloride environment," Construction and Building Materials, vol. 93, pp. 205-213, 2015.

[9] A. Kaveh, S. Allan, P. Alessandro, and C. Don, "Influence of chloride corrosion on the effective mechanical properties of steel reinforcement," Structure and Infrastructure Engineering, vol. 15, no. 8, pp. 1036-1048, 2019.

[10] Namita, Effects of Corrosion in Reinforcement: Signs \& Preventive Measures Structural Engineering, CivilDigital, CivilDigital.com, 2018.

[11] Federal Emergency Management Agency, FEMA 310 Handbook for Seismic Evaluation of Buildings-A Prestandard, Federal Emergency Management Agency, Washington, DC, USA, 1998.

[12] Federal Emergency Management Agency, FEMA 356 Prestandard and Commentary for Seismic Rehabilitation of Buildings, Federal Emergency Management Agency, Washington, DC, USA, 2000.

[13] Japan Building Disaster Prevention Association, English Version: Standard for Seismic Evaluation of Existing Reinforced Concrete Buildings, Japan Building Disaster Prevention Association, Tokyo, Japan, 2005.

[14] Y. Li, S. P. Yin, and W. j. Chen, "Seismic behavior of corrosion-damaged RC columns strengthened with TRC under a chloride environment," Construction and Building Materials, vol. 201, pp. 736-745, 2019.

[15] J. G. Cabrera, "Deterioration of concrete due to reinforcement steel corrosion," Cement and Concrete Composites, vol. 18, no. 1, pp. 47-59, 1996.

[16] R. Capozucca, "Damage to reinforced concrete due to reinforcement corrosion," Construction and Building Materials, vol. 9, no. 5, pp. 295-303, 1995.

[17] A. Wei, Y. Wang, and M. Y. J. Tan, "Monitoring corrosion of reinforced concrete beams in a chloride containing 
environment under different loading levels," Structural Monitoring and Maintenance, vol. 2, no. 3, pp. 253-267, 2015.

[18] B. Pradhan and B. Bhattacharjee, "Half-cell potential as an indicator of chloride-induced rebar corrosion initiation in RC," Journal of Materials in Civil Engineering, vol. 21, no. 10, pp. 543-552, 2009.

[19] B. Assouli, G. Ballivy, and P. Rivard, "Influence of environmental parameters on application of standard ASTM C87691: half cell potential measurements," Corrosion Engineering, Science and Technology, vol. 43, no. 1, pp. 93-96, 2008.

[20] ASTM C39/C39M-15, Standard Test Method for Compressive Strength of Cylindrical Concrete Specimens, ASTM International, West Conshohocken, PA, USA, 2015.

[21] ASTM E8/E8M-15, Standard Test Methods for Tension Testing of Metallic Materials, ASTM International, West Conshohocken, PA, USA, 2015.

[22] ACI Committee 318, Building Code Requirements for Structural Concrete and Commentary (ACI 318-11) and Commentary, American Concrete Institute, Farmington Hills, MI, USA, 2011.

[23] Proceq, CANIN+ Operating Instruction for Corrosion Analyzing Instrument, Proceq, Schwerzenbach, Switzerland, 2009.

[24] ASTM C876-09, Standard test method for corrosion potentials of uncoated reinforcing steel in concrete, ASTM International, West Conshohocken, PA, USA, 2009.

[25] P. K. Mehta and P. J. M. Monteiro, Concrete Microstructure, Properties, and Materials, McGraw-Hill Companies, New York, NY, USA, 3rd edition, 1994. 


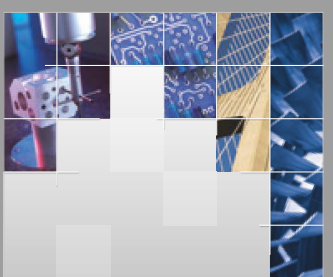

\section{Enfincering}
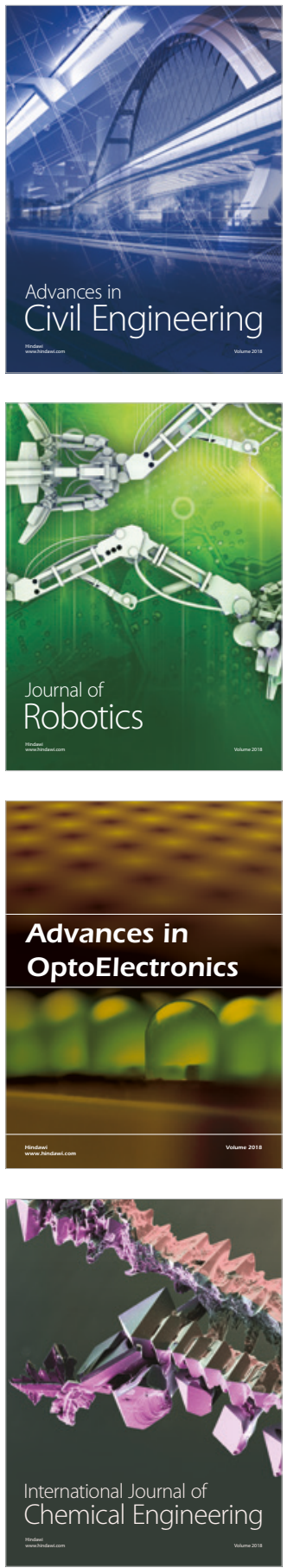

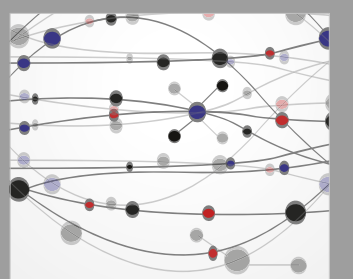

\section{Rotating \\ Machinery}

The Scientific World Journal

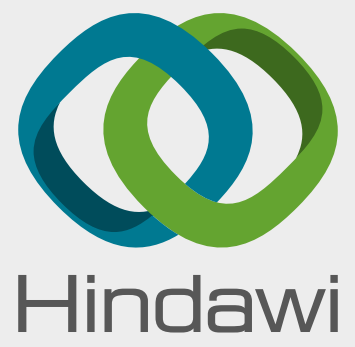

Submit your manuscripts at

www.hindawi.com
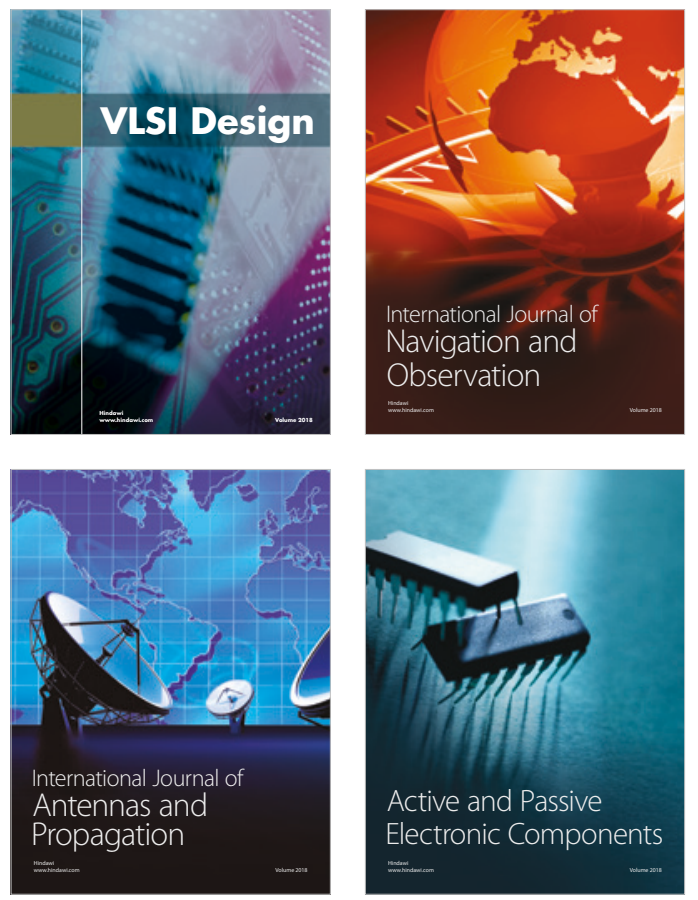
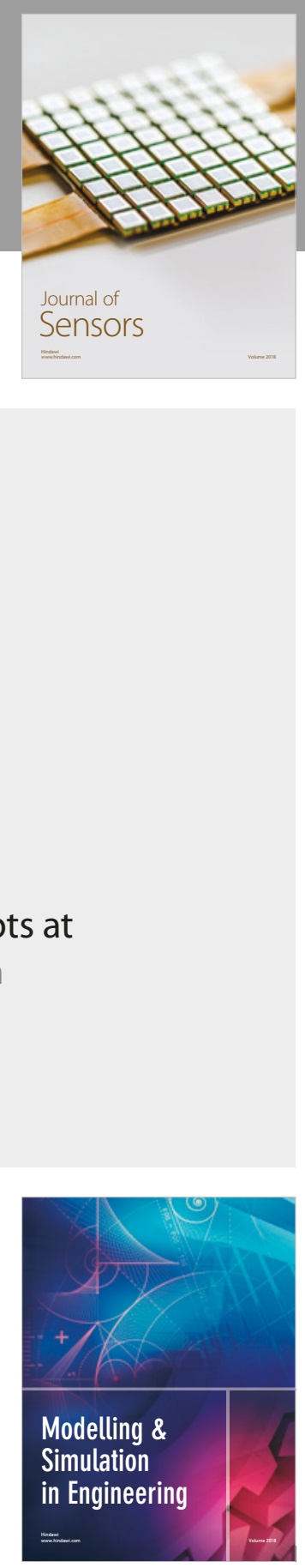

\section{Advances \\ Multimedia}
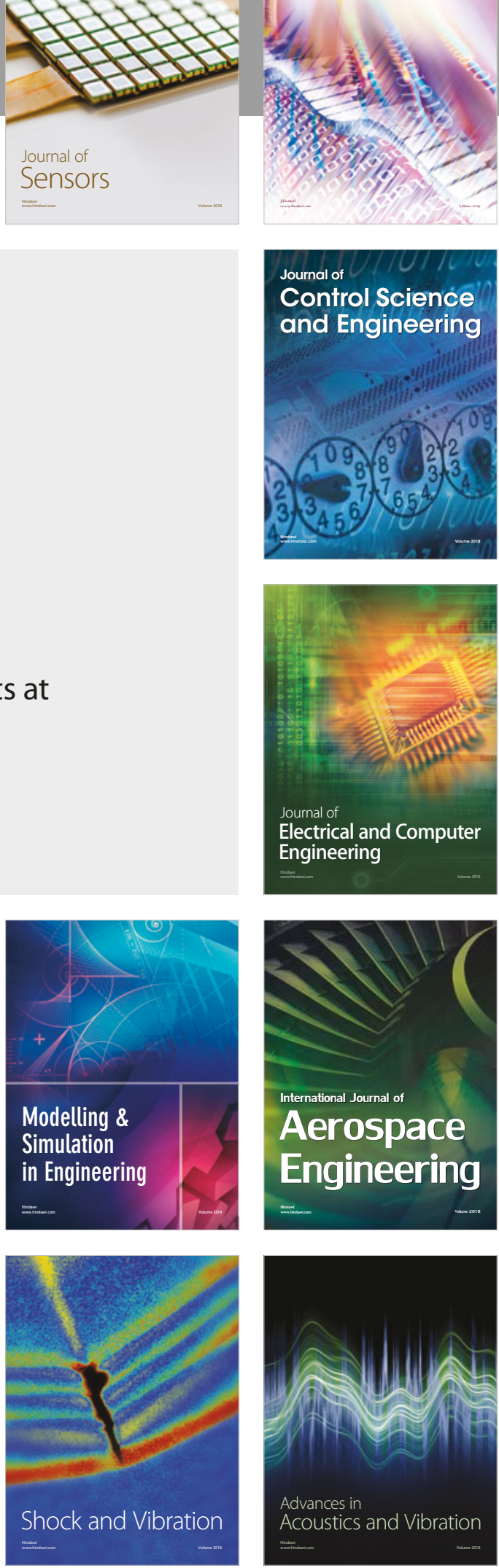